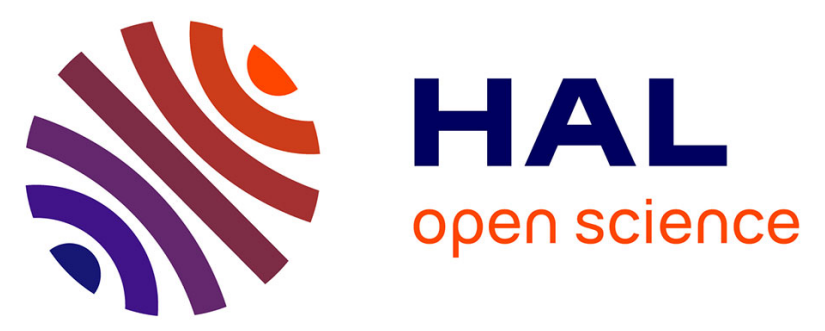

\title{
Development of highly sensitive fluorescent probes for the detection of $\beta$-galactosidase activity - application to the real-time monitoring of senescence in live cells
}

\author{
Mauro Safir Filho, Pascal Dao, Maeva Gesson, Anthony Martin, Rachid
}

Benhida

\section{To cite this version:}

Mauro Safir Filho, Pascal Dao, Maeva Gesson, Anthony Martin, Rachid Benhida. Development of highly sensitive fluorescent probes for the detection of $\beta$-galactosidase activity - application to the real-time monitoring of senescence in live cells. Analyst, 2018, 143 (11), pp.2680-2688. 10.1039/C8AN00516H . hal-02147544

\section{HAL Id: hal-02147544 \\ https://hal.science/hal-02147544}

Submitted on 4 Jun 2019

HAL is a multi-disciplinary open access archive for the deposit and dissemination of scientific research documents, whether they are published or not. The documents may come from teaching and research institutions in France or abroad, or from public or private research centers.
L'archive ouverte pluridisciplinaire HAL, est destinée au dépôt et à la diffusion de documents scientifiques de niveau recherche, publiés ou non, émanant des établissements d'enseignement et de recherche français ou étrangers, des laboratoires publics ou privés. 


\title{
Development of highly sensitive fluorescent probes for the detection of $\boldsymbol{\beta}$-galactosidase activity - application to the real-time monitoring of senescence in live cells.
}

\author{
Mauro Safir Filho, ${ }^{\mathrm{a}, \mathrm{b}, \dagger}$ Pascal Dao, ${ }^{\mathrm{a}, \dagger}$ Maéva Gesson, ${ }^{\mathrm{c}}$ Anthony R. Martin, ${ }^{\mathrm{a}, *}$ Rachid Benhida ${ }^{\mathrm{a}, *}$ \\ ${ }^{a}$ Université Côte d'Azur, CNRS, Institut de Chimie de Nice UMR7272, Nice, France \\ ${ }^{\mathrm{b}}$ CAPES Foundation, Ministry of Education of Brazil, Brasília DF 70040-020, Brazil \\ ${ }^{\text {c } U n i v e r s i t e ́ ~ C o ̂ t e ~ d ' A z u r, ~ C e n t r e ~ M e ́ d i t e r r a n e ́ e n ~ d e ~ M e ́ d e c i n e ~ M o l e ́ c u l a i r e ~(C 3 M), ~ I N S E R M ~ U 1065, ~ N i c e, ~ F r a n c e ~}$ \\ * corresponding authors: anmartin@unice.fr, benhida@unice.fr.
}

\begin{abstract}
We report the development of four novel fluorescent probes to monitor the activity of the $\beta$-galactosidase enzyme ( $\beta$-gal), in vitro and in living cells. The fluorophores are based on a 6-amino-styryl-benzothiazole push-pull core and display a strong ICT emission. The probes encompass the fluorescent motif that is connected to a $\beta$-D-galactopyranoside moiety through a self-immolative benzyl carbamate linker (及Gal-1-4). The screening of four different fluorophores enabled us to access new light-up and two-band ratiometric reporters. The four probes, $\boldsymbol{\beta}$ Gal-1-4, exhibited an extremely fast response and over 200-fold fluorescence enhancement ( $\boldsymbol{\beta G}$ Gal-1) following the enzymatic cleavage of the $\beta$-D-galactopyranoside unit. This rapid and extremely sensitive response allowed the detection of senescence-associated $\beta$-galactosidase (SA- $\beta$-gal) activity; a widely used biomarker of senescence. More importantly, $\boldsymbol{\beta G a l - 1}$ also enabled us to monitor, in realtime, the emergence of senescence in live cells, i.e. the phenotypic transformation from normal to senescent cell. These findings underpin the fact that $\boldsymbol{\beta G a l - 1}$ may find useful applications in biomedical research. Importantly, $\boldsymbol{\beta G a l - 1}$ is suitable for epifluorescence and confocal microscopies, and flow cytometry techniques; which are among the most common analytical tools in biology.
\end{abstract}

\section{Introduction}

$\beta$-galactosidase ( $\beta$-gal) is a glycoside hydrolase enzyme responsible for the hydrolysis of $\beta$-galactosides into monosaccharides by breaking the glyosidic bond. It has been widely used as the key marker enzyme for in vivo tumor growth monitoring, ${ }^{1,2}$ transcriptional regulation, ${ }^{3}$ gene expression ${ }^{4}$ and, importantly for specific characterization of cellular senescence ${ }^{5}$. Cell senescence is a persistent cytostasis which results from a nonlethal stress. It is characterized by a morphological and biochemical phenotype that includes an abnormally accumulated $\beta$-gal activity called senescence-associated $\beta$-galactosidase (SA- $\beta$-gal). This SA- $\beta$-gal activity is a widely accepted marker of cellular senescence. ${ }^{5}$

In recent years, therapy-induced senescence (TIS) attracted a lot of attention from both academic and industrial research groups interested in the development of new anti-cancer therapies. In fact, TIS appeared as a new potential mean to treat cancer by inducing the entrance of cancer cells into a cytostatic state. ${ }^{6}$ One of the main assets of TIS, as reported in several studies, ${ }^{7,8}$ is that cancer cells resistant to chemotherapy remain sensitive 
to the induction of senescence. This suggests that TIS could be widely used regardless of the resistance state of the tumors. Furthermore, activation of the immune system by senescent cells is involved in tumor clearance. ${ }^{9}$ Thus, TIS may provide an effective way to fight cancer. Unfortunately, only a few compounds have been identified as senescence inducers. Indeed, a limiting factor in the efficient discovery of senescence inducers has been the lack of powerful methods for high-throughput screening.

The most common method to visualize SA- $\beta$-gal is the widely used X-Gal assay. ${ }^{5} \mathrm{X}-\mathrm{Gal}, 5$-bromo-4-chloro3-indolyl- $\beta$-D-galactopyranoside (Fig. 1), is a synthetic substrate of $\beta$-gal which yields a blue precipitate after its processing. In parallel, different $\beta$-galactosidase fluorescent probes have also been developed. However, most of the fluorophores used for this purpose exploit the conventional coumarin, fluoresceine ${ }^{10}$ or the fluoresceine-rhodamine hybrid rhodol $\mathrm{dyes}^{11}$ as fluorescent reporters (e.g. the commercially available 4methylumbelliferyl $\beta$-D-galactopyranoside - 4-MUG - and fluorescein di- $\beta$-D-galactopyranoside - FDG derivatives; Fig. 1). Although featuring extreme sensitivity due to the brightness of the generated fluorescent products, these probes present slow kinetic response and reduced Stokes shift. Moreover, they are also unsuitable for live-cell imaging since they need to be used on fixed cells that underwent a $\mathrm{pH}$ modulation step before staining.

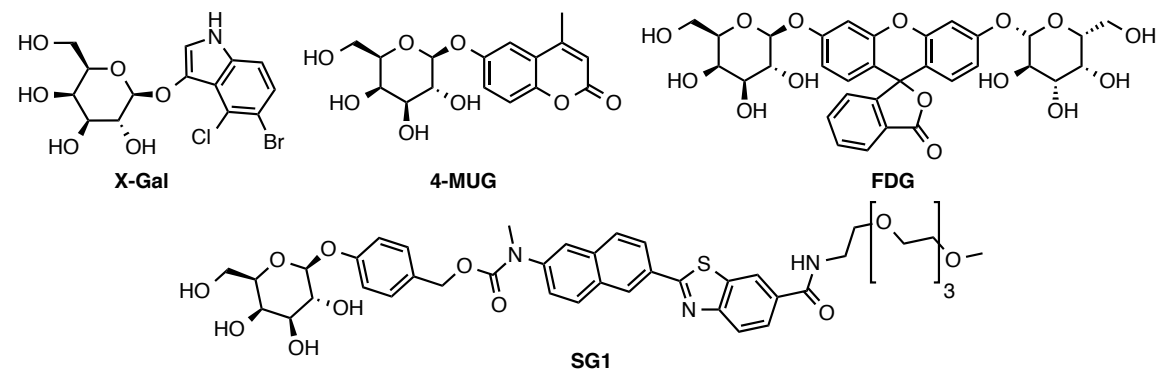

Fig 1. Chemical structures of four probes used for the visualization and detection SA- $\beta$-gal activity.

In the last years, sustained efforts have been produced to overcome these issues. Novel light-up and ratiometric $\beta$-gal, single and two-photon, fluorescent probes displaying large Stokes shift have extensively been sought after. Indeed, Zhang ${ }^{12}$ and Jinxin ${ }^{13}$ groups developed new $\beta$-gal probes based on the 4-hydroxy-1,8naphthalimide core; the fluorescent reporter displayed a strong ICT emission. In 2017, Guoyu et al. ${ }^{14}$ reported an innovative aggregation induced emission (AIE) based probe. Guoyu used a tetraphenylethylene (TPE) as the signaling motif and a $\beta$-D-galactose moiety as the enzyme substrate. Upon $\beta$-gal processing, $\beta$-D-galactose cleavage restored the aggregation properties of TPE motifs and a strong enhancement of the fluorescence signal was observed. More recently, Beatriz and co-workers ${ }^{15}$ described a turn-on fluorescent probe based on an excimer formation. The probe encompassed a 4-bromo-1,8-naphthalimide scaffold connected to a $\beta$-Dgalactose residue through a histidine linker. While featuring good properties for in vivo imaging, the probe concentrations required for cellular staining remained high $(10-20 \mu \mathrm{M})$.

Despite these significant advances in the design of fluorescent SA- $\beta$-gal probes, no reports concerning the real-time monitoring and detection of early to middle stages of cellular senescence has been considered. In 
2014, Kim and co-workers ${ }^{16}$ partially addressed this issue. They reported the two-photons ratiometric $\beta$-gal probe SG1 (Fig. 1) to detect senescence in live cells and tissues. The probe was based on a push-pull 6(benzo[d]thiazol-2'-yl)-2-(methylamino)-naphthalene fluorophore masked with a $\beta$-D-galactopyranoside connected with a benzyl carbamate linker.

Inspired by the work from Kim and co-workers, ${ }^{16}$ and based on our previous study dealing with amino containing styryl-benzothiazole fluorophores, ${ }^{17}$ we designed and developed new dyes for the monitoring of $\beta$ gal activity in live cells. These probes, $\boldsymbol{\beta}$ Gal-1-4, were designed by combining 6-amino-styryl-benzothiazole fluorophores, displaying strong ICT emission, with an enzyme-labile $\beta$-D-galactopyranoside; both moieties being linked together with a self-immolative benzyl carbamate spacer (Scheme 1). Thus, we report herein the synthesis, the in vitro (enzymatic) and in cellulo evaluation of these dyes. Additionally, we demonstrate that their use is fully compatible with fluorescent microscopy and flow cytometry methods; hence they would be adaptable to a high-throughput screening. Finally, we show that probe $\boldsymbol{\beta} \mathbf{G a l - 1}$ can be used directly on live cells without permeabilization (nor $\mathrm{pH}$ modulation) and exemplified its use by monitoring, in real-time, the appearance of induced-senescence in cancer cell lines.

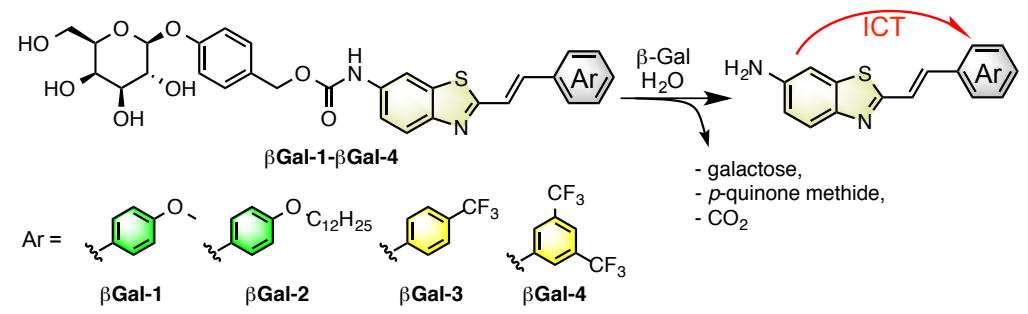

Scheme 1. $\beta$-gal probes $\boldsymbol{\beta G a l - 1 - 4}$ investigated in this work.

\section{Experimental Part}

\section{General procedure for the synthesis of fluorophores 2-5.}

2-methylbenzo[d]thiazol-6-amine (1, $2.0 \mathrm{mmol}, 1$ equiv.) in DMF (0.2 M), potassium hydroxide (2.0 mmol, 1 equiv.), and the aldehyde ( $2.6 \mathrm{mmol}, 1.3$ equiv.) were stirred for 12 hours at room temperature. The solvent was removed in vacuo, and the residue suspended in water. After acidification to $\mathrm{pH} 1$ using concentrated $\mathrm{HCl}$, the aqueous layer was extracted with ethyl acetate to remove the aldehyde in excess. The aqueous layer was neutralized with $\mathrm{NaOH}(1 \mathrm{M})$ and extracted with ethyl acetate. The organic layer was dried over magnesium sulfate, filtered and the volatiles were removed in vacuo. The crude was purified by flash column chromatography on silica gel using cyclohexane/ethyl acetate (Cy/EA) mixtures as the eluent. Finally, recrystallization from methanol afforded the desired fluorophores, 2-5, as bright solids.

(E)-2-(4-methoxystyryl)benzo[d]thiazol-6-amine, $2 .{ }^{17}$ Starting from $328 \mathrm{mg}$ of $\mathbf{1}$, compound 2 was obtained in $65 \%$ yield after purification on silica gel column chromatography (eluent: Cy/EA - 80/20) and recrystallization from methanol. ${ }^{1} \mathrm{H} \mathrm{NMR}\left(400 \mathrm{MHz}, \mathrm{CDCl}_{3}\right) \delta 7.74(\mathrm{~d}, J=8.6 \mathrm{~Hz}, 1 \mathrm{H}), 7.49(\mathrm{~d}, J=8.7 \mathrm{~Hz}$, 2H), $7.32(\mathrm{~d}, J=16.2 \mathrm{~Hz}, 1 \mathrm{H}), 7.22(\mathrm{~d}, J=16.2 \mathrm{~Hz}, 1 \mathrm{H}), 7.08(\mathrm{~d}, J=2.2 \mathrm{~Hz}, 1 \mathrm{H}), 6.92(\mathrm{~d}, J=8.7 \mathrm{~Hz}, 2 \mathrm{H})$, $6.80(\mathrm{dd}, J=8.6,2.3 \mathrm{~Hz}, 1 \mathrm{H}), 3.84(\mathrm{~s}, 3 \mathrm{H}), 3.84$ (br s, 2H). ${ }^{13} \mathrm{C} \mathrm{NMR}\left(101 \mathrm{MHz}, \mathrm{CDCl}_{3}\right) \delta 163.6,160.6$, $147.5,144.7,136.2,135.8,128.8,128.7,123.4,120.5,115.7,114.5,105.8,55.5$. 
(E)-2-(4-(dodecyloxy)styryl)benzo[d]thiazol-6-amine, 3. Starting from $328 \mathrm{mg}$ of 1, compound 3 was obtained in 53\% yield after purification on silica gel column chromatography (eluent: $\mathrm{Cy} / \mathrm{EA}-80 / 20$ ) and recrystallization from methanol. ${ }^{1} \mathrm{H} \mathrm{NMR}\left(400 \mathrm{MHz}, \mathrm{CDCl}_{3}\right) \delta 7.73(\mathrm{~d}, J=8.6 \mathrm{~Hz}, 1 \mathrm{H}), 7.47(\mathrm{~d}, J=8.2 \mathrm{~Hz}$, 2H), $7.32(\mathrm{~d}, J=16.2 \mathrm{~Hz}, 1 \mathrm{H}), 7.21(\mathrm{~d}, J=16.2 \mathrm{~Hz}, 1 \mathrm{H}), 7.07(\mathrm{~s}, 1 \mathrm{H}), 6.91(\mathrm{~d}, J=8.1 \mathrm{~Hz}, 2 \mathrm{H}), 6.80(\mathrm{~d}, J=$ $8.6 \mathrm{~Hz}, 1 \mathrm{H}), 3.98(\mathrm{t}, J=6.4 \mathrm{~Hz}, 2 \mathrm{H}), 3.83(\mathrm{~s}, 2 \mathrm{H}), 1.87-1.76(\mathrm{~m}, 2 \mathrm{H}), 1.47-1.44(\mathrm{~m}, 2 \mathrm{H}), 1.32-1.27(\mathrm{~m}$, $16 \mathrm{H}), 0.88(\mathrm{t}, J=6.4 \mathrm{~Hz}, 3 \mathrm{H}) .{ }^{13} \mathrm{C} \mathrm{NMR}\left(101 \mathrm{MHz}, \mathrm{CDCl}_{3}\right) \delta 163.7,160.2,147.5,144.7,136.2,135.9,128.7$, 128.4, 123.4, 120.3, 115.7, 115.0, 105.8, 68.3, 32.1, 29.8, 29.8, 29.7, 29.7, 29.5, 29.5, 29.4, 26.2, 22.8, 14.3. HRMS (ESI) m/z: [M + H] $]^{+}$Calcd for $\mathrm{C}_{27} \mathrm{H}_{37} \mathrm{~N}_{2} \mathrm{OS}$ 437.2627; Found 437.2622.

(E)-2-(4-(trifluoromethyl)styryl)benzo[d]thiazol-6-amine, 4. Starting from $328 \mathrm{mg}$ of 1, compound 4 was obtained in $43 \%$ yield after purification on silica gel column chromatography (eluent: Cy/EA - 80/20) and recrystallization from methanol. ${ }^{1} \mathrm{H} \mathrm{NMR}\left(400 \mathrm{MHz}, \mathrm{CDCl}_{3}\right) \delta 7.78(\mathrm{~d}, J=8.7 \mathrm{~Hz}, 1 \mathrm{H}), 7.64(\mathrm{~s}, 4 \mathrm{H}), 7.43(\mathrm{~d}$, $J=16.3 \mathrm{~Hz}, 1 \mathrm{H}), 7.37$ (d, $J=16.3 \mathrm{~Hz}, 1 \mathrm{H}), 7.10$ (d, $J=2.1 \mathrm{~Hz}, 1 \mathrm{H}), 6.84$ (dd, $J=8.7,2.3 \mathrm{~Hz}, 1 \mathrm{H}), 3.90$ (s, 2H). ${ }^{19} \mathrm{~F} \mathrm{NMR}\left(376 \mathrm{MHz}, \mathrm{CDCl}_{3}\right) \delta-62.66 .{ }^{13} \mathrm{C} \mathrm{NMR}\left(101 \mathrm{MHz}, \mathrm{CDCl}_{3}\right) \delta 162.1,147.4,145.3,139.3,136.6$, 133.9, 130.6 (q, $J=33 \mathrm{~Hz}), 127.3,126.0$ (q, $J=4 \mathrm{~Hz}), 124.9,124.2$ (q, $J=272 \mathrm{~Hz}), 123.9,116.0,105.6$. HRMS (ESI) m/z: [M + H] Calcd for $\mathrm{C}_{16} \mathrm{H}_{12} \mathrm{~F}_{3} \mathrm{~N}_{2} \mathrm{~S}$ 321.0673; Found 321.0669.

(E)-2-(3,5-bis(trifluoromethyl)styryl)benzo[d]thiazol-6-amine, 5. Starting from $328 \mathrm{mg}$ of 1, compound 5 was obtained in $62 \%$ yield after purification on silica gel column chromatography (eluent: Cy/EA - 85/15) and recrystallization from methanol. ${ }^{1} \mathrm{H}$ NMR $\left(400 \mathrm{MHz}, \mathrm{CDCl}_{3}\right) \delta 7.96(\mathrm{~s}, 2 \mathrm{H}), 7.81-7.79(\mathrm{~m}, 2 \mathrm{H}), 7.48(\mathrm{~d}$, $J=16.2 \mathrm{~Hz}, 1 \mathrm{H}), 7.40$ (d, $J=16.3 \mathrm{~Hz}, 1 \mathrm{H}), 7.10$ (d, $J=2.2 \mathrm{~Hz}, 1 \mathrm{H}), 6.85$ (dd, $J=8.7,2.3 \mathrm{~Hz}, 1 \mathrm{H}), 3.92$ (br s, 2H). ${ }^{19} \mathrm{~F} \mathrm{NMR}\left(376 \mathrm{MHz}, \mathrm{CDCl}_{3}\right) \delta-62.40 .{ }^{13} \mathrm{C} \mathrm{NMR}\left(101 \mathrm{MHz}, \mathrm{CDCl}_{3}\right) \delta 161.0,147.4,145.5,138.1$, $136.8,132.5$ (q, $J=33 \mathrm{~Hz}), 131.9,126.9-126.8(\mathrm{~m}), 126.2,124.2,123.3$ (q, $J=273 \mathrm{~Hz}), 122.2-122.0(\mathrm{~m})$, 116.2, 105.5. HRMS (ESI) m/z: $[\mathrm{M}+\mathrm{H}]^{+}$Calcd for $\mathrm{C}_{17} \mathrm{H}_{11} \mathrm{~F}_{6} \mathrm{~N}_{2} \mathrm{~S} 389.0547$; Found 389.0545.

\section{General procedure for the synthesis of probes $\beta \mathrm{Gal}-1-4$.}

The probe precursor $(0.7 \mathrm{mmol}, \mathbf{2 - 5}, 1$ equiv.) was dissolved in dry 1,4-dioxane $(20 \mathrm{~mL})$ with 3 equivalents of triethylamine. This solution was added dropwise, over a period of 10 minutes, to a solution containing an equimolar amount of triphosgene $(0.7 \mathrm{mmol}, 1$ equiv. $)$ in dry 1,4-dioxane $(5 \mathrm{~mL})$. The mixture was stirred at room temperature until complete conversion of the starting material (analyzed by LC/MS, sample diluted in methanol). Then, benzyl alcohol 6 was added ( $0.7 \mathrm{mmol}, 1$ equiv.) and the mixture was stirred overnight at room temperature. Subsequently, the solids were filtered off, the crude filtrate was adsorbed onto silica and purified by flash column chromatography ( $\mathrm{Cy} / \mathrm{EA}$ as eluting mixtures) to afford the respective tetra- $O$ -

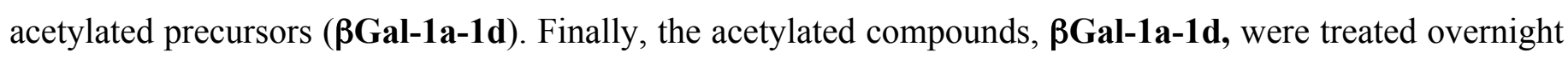
with sodium methoxide ( $3.5 \mathrm{mmol}, 5$ equiv.) in methanol $(0.1 \mathrm{M})$. The precipitates were collected by filtration, washed with methanol and dichloromethane to afford the final $\mathbf{\beta G a l - 1 - 4}$ probes as colorless solids.

4-(((2S,3R,4S,5R,6R)-3,4,5-trihydroxy-6-(hydroxymethyl)tetrahydro-2H-pyran-2-yl)oxy)benzyl (2-((E)-4methoxystyryl)benzo[d]thiazol-6-yl)carbamate, $\beta$ Gal-1. Starting from $200 \mathrm{mg}$ of 2, $\beta$ Gal-1 was obtained in $18 \%$ yield. Intermediate $\boldsymbol{\beta G a l - 1 a}$ was purified on silica gel column chromatography using Cy/EA (0-50 \% 
EA) as the eluent mixture. ${ }^{1} \mathrm{H}$ NMR (400 MHz, DMSO- $\left.d 6\right) \delta 10.02(\mathrm{~s}, 1 \mathrm{H}), 8.22(\mathrm{~s}, 1 \mathrm{H}), 7.83(\mathrm{~d}, J=8.6 \mathrm{~Hz}$, 1H), $7.71(\mathrm{~d}, J=7.4 \mathrm{~Hz}, 2 \mathrm{H}), 7.54-7.37(\mathrm{~m}, 5 \mathrm{H}), 7.05-6.99(\mathrm{~m}, 4 \mathrm{H}), 5.15$ (brs, 1H), 5.11 (s, $2 \mathrm{H}), 4.87$ (brs, $1 \mathrm{H}), 4.83(\mathrm{~d}, J=5.9 \mathrm{~Hz}, 1 \mathrm{H}), 4.64(\mathrm{brs}, 1 \mathrm{H}), 4.54$ (brs, 1H), $3.80(\mathrm{~s}, 3 \mathrm{H}), 3.69(\mathrm{~s}, 1 \mathrm{H}), 3.56-3.41(\mathrm{~m}, 5 \mathrm{H})$.

${ }^{13} \mathrm{C}$ NMR (101 MHz, DMSO-d6) $\delta 165.1,160.3,157.4,153.5,149.1,136.9,136.6,134.7,129.9,129.6,129.2$, $127.9,122.4,119.6,118.1,116.2,114.4,110.0,100.9,75.5,73.3,70.3,68.1,65.7,60.4,55.3$. HRMS (ESI) $\mathrm{m} / \mathrm{z}:[\mathrm{M}+\mathrm{H}]^{+}$Calcd for $\mathrm{C}_{30} \mathrm{H}_{31} \mathrm{~N}_{2} \mathrm{O}_{9} \mathrm{~S}$ 595.1750; Found 595.1747.

4-(((2S,3R,4S,5R,6R)-3,4,5-trihydroxy-6-(hydroxymethyl)tetrahydro-2H-pyran-2-yl)oxy)benzyl (2-((E)-4(dodecyloxy)styryl)benzo[d]thiazol-6-yl)carbamate, $\beta$ Gal-2. Starting from $305 \mathrm{mg}$ of 3, $\boldsymbol{\beta}$ Gal-2 was obtained in $14 \%$ yield. Intermediate $\boldsymbol{\beta G a l - 2 a}$ was purified on silica gel column chromatography using $\mathrm{Cy} / \mathrm{EA}(0-50 \%$ EA) as the eluent mixture. ${ }^{1} \mathrm{H}$ NMR (400 MHz, DMSO-d6) $\delta 10.02(\mathrm{~s}, 1 \mathrm{H}), 8.22(\mathrm{~s}, 1 \mathrm{H}), 7.83(\mathrm{~d}, J=8.7 \mathrm{~Hz}$, 1H), $7.69(\mathrm{~d}, J=8.1 \mathrm{~Hz}, 2 \mathrm{H}), 7.53-7.46(\mathrm{~m}, 2 \mathrm{H}), 7.41-7.37(\mathrm{~m}, 3 \mathrm{H}), 7.01(\mathrm{dd}, J=28.6,8.2 \mathrm{~Hz}, 4 \mathrm{H}), 5.16$ (br s, 1H), 5.12 (s, 2H), 4.88 (br s, 1H), $4.84(\mathrm{~d}, J=7.5 \mathrm{~Hz}, 1 \mathrm{H}), 4.64$ (br s, 1H), 4.52 (br s, 1H), 4.00 (t, $J=$ $6.0 \mathrm{~Hz}, 2 \mathrm{H}), 3.69(\mathrm{~s}, 1 \mathrm{H}), 3.58-3.54(\mathrm{~m}, 3 \mathrm{H}), 3.46-3.50(\mathrm{~m}, J=4.7 \mathrm{~Hz}, 1 \mathrm{H}), 3.41-3.39(\mathrm{~m}, 1 \mathrm{H}), 1.73-$ $1.67(\mathrm{~m}, 2 \mathrm{H}), 1.40-1.39(\mathrm{~m}, 2 \mathrm{H}), 1.35-1.24(\mathrm{~m}, 16 \mathrm{H}), 0.84(\mathrm{t}, J=6.5 \mathrm{~Hz}, 3 \mathrm{H}) .{ }^{13} \mathrm{C} \mathrm{NMR}(101 \mathrm{MHz}$, DMSO- $d 6) \delta 165.1,159.8,157.4,153.5,149.1,136.8,136.6,134.7,129.9,129.6,129.2,127.7,122.4,119.5$, 118.1, 116.2, 114.8, 109.9, 75.5, 73.3, 70.2, 68.1, 67.6, 65.7, 60.4, 31.3, 29.0, 29.0, 28.9, 28.9 28.7, 28.7, 28.6, 25.5, 22.1, 13.9. HRMS (ESI) m/z: $[\mathrm{M}+\mathrm{H}]^{+}$Calcd for $\mathrm{C}_{41} \mathrm{H}_{53} \mathrm{~N}_{2} \mathrm{O}_{9} \mathrm{~S}$ 749.3472; Found 749.3467.

4-(((2S,3R,4S,5R,6R)-3,4,5-trihydroxy-6-(hydroxymethyl)tetrahydro-2H-pyran-2-yl)oxy)benzyl (2-((E)-4(trifluoromethyl)styryl)benzo[d]thiazol-6-yl)carbamate, $\boldsymbol{\beta G a l - 3 . ~ S t a r t i n g ~ f r o m ~} 224 \mathrm{mg}$ of 4, $\mathbf{\beta G a l - 3}$ was obtained in $21 \%$ yield. Intermediate $\beta$ Gal-3a was purified on silica gel column chromatography using Cy/EA $\left(0-50 \%\right.$ EA) as the eluent mixture. ${ }^{1} \mathrm{H}$ NMR (400 MHz, DMSO- $\left.d 6\right) \delta 10.07$ (s, 1H), $8.28(\mathrm{~s}, 1 \mathrm{H}), 7.99$ (d, $J$ $=8.2 \mathrm{~Hz}, 2 \mathrm{H}), 7.91(\mathrm{~d}, J=8.9 \mathrm{~Hz}, 1 \mathrm{H}), 7.82-7.71(\mathrm{~m}, 3 \mathrm{H}), 7.67(\mathrm{~d}, J=16.3 \mathrm{~Hz}, 1 \mathrm{H}), 7.51(\mathrm{dd}, J=8.9,2.0$ $\mathrm{Hz}, 1 \mathrm{H}), 7.39$ (d, $J=8.6 \mathrm{~Hz}, 2 \mathrm{H}), 7.05(\mathrm{~d}, J=8.6 \mathrm{~Hz}, 2 \mathrm{H}), 5.17(\mathrm{~d}, J=5.1 \mathrm{~Hz}, 1 \mathrm{H}), 5.12(\mathrm{~s}, 2 \mathrm{H}), 4.86(\mathrm{~d}, J=$ $5.7 \mathrm{~Hz}, 1 \mathrm{H}), 4.84(\mathrm{~d}, J=7.7 \mathrm{~Hz}, 1 \mathrm{H}), 4.64(\mathrm{t}, J=5.4 \mathrm{~Hz}, 1 \mathrm{H}), 4.50(\mathrm{~d}, J=4.6 \mathrm{~Hz}, 1 \mathrm{H}), 3.70(\mathrm{t}, J=3.9 \mathrm{~Hz}$, $1 \mathrm{H}), 3.60-3.52(\mathrm{~m}, 3 \mathrm{H}), 3.52-3.45(\mathrm{~m}, 1 \mathrm{H}), 3.44-3.37(\mathrm{~m}, 1 \mathrm{H}) .{ }^{19} \mathrm{~F}$ NMR (376 MHz, DMSO-d6) $\delta-61.06$. ${ }^{13} \mathrm{C}$ NMR (101 MHz, DMSO-d6) $\delta$ 163.9, 157.4, 153.5, 149.0, 139.4, 137.3, 135.2, 134.7, 129.9, 129.5, 128.9 (q, $J=32 \mathrm{~Hz}), 125.7$ (q, $J=3 \mathrm{~Hz}), 124.6,124.2$ (q, $J=271 \mathrm{~Hz}), 122.9,118.3,116.2,109.9,100.9,75.5,73.3$, 70.3, 68.1, 65.8, 60.4. HRMS (ESI) m/z: [M+ H] Calcd for $\mathrm{C}_{30} \mathrm{H}_{28} \mathrm{~F}_{3} \mathrm{~N}_{2} \mathrm{O}_{8} \mathrm{~S}$ 633.1518; Found 633.1514.

4-(((2S,3R,4S,5R,6R)-3,4,5-trihydroxy-6-(hydroxymethyl)tetrahydro-2H-pyran-2-yl)oxy)benzyl (2-((E)-

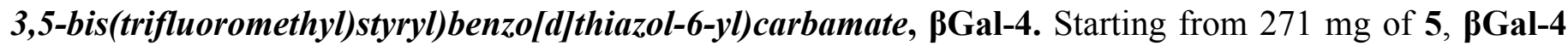
was obtained in $12 \%$ yield. Intermediate $\boldsymbol{\beta G a l - 4 a}$ was purified on silica gel column chromatography using Cy/EA (0-50 \% EA) as the eluent mixture. ${ }^{1} \mathrm{H}$ NMR (400 MHz, DMSO-do) $\delta 10.08(\mathrm{~s}, 1 \mathrm{H}), 8.52(\mathrm{~s}, 2 \mathrm{H}), 8.30$ $(\mathrm{d}, J=1.5 \mathrm{~Hz}, 1 \mathrm{H}), 8.05(\mathrm{~s}, 1 \mathrm{H}), 8.00(\mathrm{~d}, J=16.3 \mathrm{~Hz}, 1 \mathrm{H}), 7.92(\mathrm{~d}, J=8.9 \mathrm{~Hz}, 1 \mathrm{H}), 7.80(\mathrm{~d}, J=16.3 \mathrm{~Hz}, 1 \mathrm{H})$, $7.52(\mathrm{dd}, J=8.9,2.1 \mathrm{~Hz}, 1 \mathrm{H}), 7.39$ (d, $J=8.7 \mathrm{~Hz}, 2 \mathrm{H}), 7.05$ (d, $J=8.6 \mathrm{~Hz}, 2 \mathrm{H}), 5.16(\mathrm{~s}, 1 \mathrm{H}), 5.13$ (brs, 2H), 4.86 (brs, 1H), 4.84 (d, $J=7.7 \mathrm{~Hz}, 1 \mathrm{H}), 4.64$ (brs, 1H), 4.51 (brs, $1 \mathrm{H}), 3.70$ (d, $J=2.7 \mathrm{~Hz}, 1 \mathrm{H}), 3.59-3.53$ $(\mathrm{m}, 3 \mathrm{H}), 3.51-3.46(\mathrm{~m}, 1 \mathrm{H}), 3.42-3.39(\mathrm{~m}, 1 \mathrm{H}) .{ }^{19} \mathrm{~F}$ NMR $(377 \mathrm{MHz}, \mathrm{DMSO}-d \sigma) \delta-61.29 .{ }^{13} \mathrm{C}$ NMR $(101$ MHz, DMSO) $\delta 163.7,157.4,153.5,149.0,138.3,137.5,135.4,133.0,130.9$ (q, $J=33 \mathrm{~Hz}), 129.9,129.5$, 
$128.0(\mathrm{q}, J=2 \mathrm{~Hz}), 125.8,123.3(\mathrm{q}, J=273 \mathrm{~Hz}), 123.0,121.9-121.8(\mathrm{~m}), 118.4,116.2,110.0,100.9,75.5$, 73.3, 70.3, 68.1, 65.8, 60.4, 40.2, 39.9, 39.7, 39.5, 39.3, 39.1, 38.9. HRMS (ESI) m/z: $[\mathrm{M}+\mathrm{H}]^{+}$Calcd for $\mathrm{C}_{31} \mathrm{H}_{27} \mathrm{~F}_{6} \mathrm{~N}_{2} \mathrm{O}_{8} \mathrm{~S}$ 701.1392; Found 701.1388.

\section{Cell experiments}

Human melanoma A375 cells and human colorectal adenocarcinoma HT-29 cells were obtained from American Type Culture Collection (ATCC, Manassas, VA, USA). A375 and HT-29 cells were cultured in Dubelcco's Modified Eagle's Medium (DMEM) containing 10\% fetal bovine serum (FSB) and 5\% penicillin/streptomycin at $37^{\circ} \mathrm{C}$ in a $5 \% \mathrm{CO}_{2}$ incubator.

\section{Live cells and fixed cells fluorescence imaging}

For fixed imaging, glass cover slips were placed into 6-well plate and A375 and HT-29 were plated at $8 \times 10^{4}$ cells/well and incubated at $37^{\circ} \mathrm{C}$ in a $5 \% \mathrm{CO}_{2}$ incubator overnight. On the next day, the cells were incubated with $50 \mu \mathrm{M}$ hydroxyurea (HU) to induce senescence. Cells without any treatment were used as negative controls. After 96 h, cells were washes with PBS before incubated 30 min with $0.1 \mu \mathrm{M} \mathbf{\beta G a l - 1}$ at $37^{\circ} \mathrm{C}$. Samples were washes with PBS and fixed with paraformaldehyde $4 \%$ before the coverslips were mounted onto a microscope slide with Fluoromount aqueous mounting medium (Sigma Aldrich) before fluorescence imaging.

For live cells imaging, A375 cells were plated on a 4-well $\mu$-slides (Ibidi) at $4 \times 10^{4}$ cells/well and incubated at $37^{\circ} \mathrm{C}$ in a $5 \% \mathrm{CO}_{2}$ incubator overnight. On the next day, $0.1 \mu \mathrm{M} \mathbf{\beta G a l - 1}$ was added before the induction of senescence using $50 \mu \mathrm{M} \mathrm{HU}$, then fluorescence imaging was performed every $24 \mathrm{~h}$.

Confocal fluorescent imaging was performed using a confocal microscope Nikon A1R scan head on a Nikon Eclipse Ti stand, using a Plan Apo 63X oil 1.4 NA objective. The excitation channel used was a LASER diode $405 \mathrm{~nm}$ and the emission signal was collected with an internal PMT detector equipped with a 450/50 filter set, and the transmission signal was collected on an external PMT. Fluorescence intensity quantification was done using Fiji. ${ }^{18}$

\section{Flow cytometry analysis}

A375 cells were plated on 12 -well plates at $8 \times 10^{4}$ cells/well and incubated at $37^{\circ} \mathrm{C}$ in a $5 \% \mathrm{CO}_{2}$ incubator overnight. On the next day, the cells were treated with HU to induce senescence. After $72 \mathrm{~h}$, trypsinized cells were washed with PBS $2 \%$ BSA and incubated 30 min with $0.1 \mu \mathrm{M} \boldsymbol{\beta}$ Gal-1 at $37^{\circ} \mathrm{C}$. After washes, cells were analyzed by FACS on a MACSQuant VYB (Myltenyi).

\section{Characterization}

All NMR spectra $\left({ }^{1} \mathrm{H},{ }^{13} \mathrm{C}\right.$ and $\left.{ }^{19} \mathrm{~F}\right)$ were recorded on $400 \mathrm{MHz}$ Bruker Advance Spectrometer with samples dissolved either in $\mathrm{CDCl}_{3}$ or DMSO- $d_{6}$. Solvent residual signals were used as internal references: $7.26 \mathrm{ppm}$ for $\mathrm{CDCl}_{3}$ and $2.50 \mathrm{ppm}$ for DMSO- $d_{6}$ for ${ }^{1} \mathrm{H}$ NMR experiments, and $77.16 \mathrm{ppm}$ for $\mathrm{CDCl}_{3}$ and $39.52 \mathrm{ppm}$ 
for DMSO- $d_{6}$ for ${ }^{13} \mathrm{C}$ NMR experiments. High Resolution Mass Spectra (HRMS) were recorded on a ThermoFisher Q Exactive (ESI-MS) at a resolution of 140000 at $\mathrm{m} / \mathrm{z} 200$. Fluorescence emission spectra were recorded in PBS buffer solutions on FluoroMax 4.0 spectrofluorometer (Jobin Yvon, Horiba). Fluorescence emission spectra in cells were recorded on a synergy H1 microplate reader (Biotek) with $\lambda_{\mathrm{exc}}=$ $405 \mathrm{~nm}$ as excitation wavelength. Supplementary data associated with this article include: photophysical characterizations, copies of NMR spectra. see ESI $\dagger$ for more details.

\section{Synthesis}

The synthetic route to the $\mathbf{\beta G a l - 1 - 4}$ probes is depicted on Scheme 2. Starting from the 2-methyl-6aminobenzothiazole 1, the corresponding dye reporters 2-5 were obtained in one step via the condensation reaction of 1 with the respective substituted benzaldehyde (Scheme 2). Then, the preparation of acetylated BGal-1a-4a probes was performed in one-pot two-step fashion. Firstly, fluorophores 2-5 were converted to the corresponding carbamoyl chlorides by treatment with equimolar amount of triphosgene, in presence of triethylamine. After complete conversion of the starting material, the intermediate was treated with the benzyl alcohol 6 (Scheme 3), ${ }^{19}$ to afford the acetylated probes $\boldsymbol{\beta G a l - 1 a - 4 a . ~ F i n a l l y , ~ p r o b e s ~} \boldsymbol{\beta G a l - 1 - 4}$ were obtained after cleavage of the acetyl groups in presence of sodium methoxide in methanol.

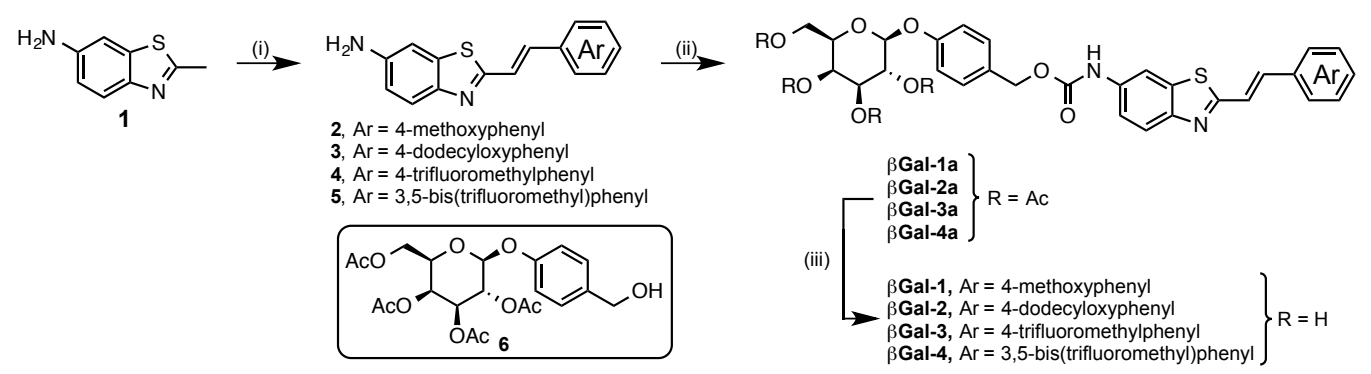

Scheme 2. Synthetic route to $\mathbf{\beta G a l - 1 - 4 . ~ R e a g e n t s ~ a n d ~ c o n d i t i o n s : ~ ( i ) ~ b e n z a l d e h y d e ~ d e r i v a t i v e ~ ( 1 . 2 ~ e q u i v . ) , ~}$ $\mathrm{KOH}$ (1 equiv.), DMF, r.t., 12 h. (ii) a) triphosgene (1 equiv.), triethylamine (3 equiv.), 1,4-dioxane, r.t., 1 h. b) 6 (1 equiv.), r.t., overnight. (iii) $\mathrm{MeONa}$ (5 equiv.), $\mathrm{MeOH}$, r.t., overnight.

\section{Photophysical Properties}

Prior to the investigation concerning the $\beta$-gal activity detection, we briefly evaluated the photophysical properties of the four fluorescent reporters (2-5) and the corresponding probes $\boldsymbol{\beta G G a l - 1 - 4}$ in four different systems (1,4-dioxane, ethyl acetate, dimethylsulfoxide and PBS containing $20 \%$ of DMSO; Fig. S1, S2 and Table S1). Interestingly, two different sets of behavior could be observed within this probe family. Firstly, dyes 2-5 displayed intense emission in the visible spectrum when excited on the near-UV region $(\sim 380 \mathrm{~nm})$. The emission maxima showed gradual redshift in solvents with increased polarity. This occurs when a relaxed excited state is more polar than the ground state. In this case, stronger interaction between the solute and the solvent reduces the energy of the excited state. Therefore, the solvatochromic effect and the large Stokes shifts highlight that these fluorophores present charge separation, such as a remarkable intramolecular charge transfer (ICT) character in the excited state. High fluorescence quantum yield values were obtained in organic solvents (Table S1), with no strong dependency of the solvent polarity. Dyes $\mathbf{4}$ and $\mathbf{5}$, bearing the 
trifluoromethylated groups, show higher level of solvent dependency compared with dyes $\mathbf{2}$ and $\mathbf{3}$. Their emission maxima $\left(\lambda_{\text {em }}\right)$ were $35 \mathrm{~nm}$ bathochromicaly shifted (560 vs $525 \mathrm{~nm}$ ) in mixtures of PBS/DMSO (8/2) compared with dyes $\mathbf{2}$ and $\mathbf{3}$. It is known that fluorescent probes displaying ICT emission are usually quenched in water. ${ }^{20}$ However, dyes $\mathbf{2}$ and $\mathbf{4}$ are still relatively bright in highly aqueous environment $\left(\phi_{\mathrm{fl}}=0.32\right.$ and 0.30 , respectively in PBS/DMSO 8/2).

Conversion of the fluorescent reporters 2-5 to the corresponding probes ( $\boldsymbol{\beta G a l - 1 - 4 )}$ by the introduction of the carbamate moiety had different effects. In fact, the acylation of the $-\mathrm{NH}_{2}$ group of dyes $\mathbf{2 - 5}$ strongly modulated their absorption and fluorescence emission maxima. The absorption maxima of $\boldsymbol{\beta G a l - 1 - 4}$ were blueshifted $\left(\lambda_{\mathrm{abs}}=361-370 \mathrm{~nm}\right)$ compared with their respective dye reporters $2-5\left(\lambda_{\mathrm{abs}}=375-410 \mathrm{~nm}\right)$. The same tendency was observed on the fluorescence emission maxima. Probes $\boldsymbol{\beta}$ Gal-1-4 displayed emission in the blue spectral region $\left(\lambda_{\mathrm{em}}=426-480 \mathrm{~nm}\right)$, with no significant solvent dependency. Interestingly, probes $\boldsymbol{\beta G a l - 1}$ and $\boldsymbol{\beta}$ Gal-2 bearing the donating groups on the acceptor side ( $p$-OMe and $p$ - $\mathrm{OC}_{12} \mathrm{H}_{25}$ ) were highly quenched in all solvents. $\left(\phi_{\mathrm{fl}}<0.005\right)$. By contrast, probes containing the fluorinated groups $(\boldsymbol{\beta G a l - 3}$ and $\boldsymbol{\beta} \mathbf{G a l}-4)$ were found to display intense fluorescence emission in all solvents $\left(\phi_{\mathrm{fl}}=0.21-0.41\right)$. However, they were poorly soluble in PBS buffer solution where they presumably form highly emissive aggregates. This aggregation may block the major non-radiative deactivation pathways by constraining molecular motion, hence enhancing/inducing their fluorescence emission in aqueous media. ${ }^{21,22}$ The formation of aggregates $\boldsymbol{\beta G a l - 3}$ and $\boldsymbol{\beta G a l - 4}$ was hypothesized as sequential acquisitions of fluorescence emission spectra of $\boldsymbol{\beta G} \mathbf{G l - 3}$ and $\boldsymbol{\beta G a l -}$ 4 revealed a continuous and time-dependent drop of the emission intensity as the putative aggregates did sediment. This observation was further confirmed as the centrifuged solution (13000 rpm, $10 \mathrm{~min}$.) was not fluorescent anymore; the aggregates being at the bottom of the cuvette (Fig. S3). ${ }^{23}$

Lastly, probe $\boldsymbol{\beta G a l - 2}$ and its corresponding dye reporter $\mathbf{3}$ were found to be too poorly emissive and soluble to be investigated further. Thereby, these first observations allowed us to potentially access a new set of

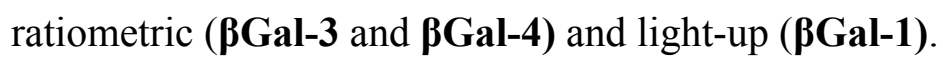

Next, we started to investigate the response of compounds $\boldsymbol{\beta G a l - 1 , 3 - 4}$ as effective reporters of $\beta$-gal activity. As a preliminary screening, fluorescence emission spectra of the probes in simulated physiological conditions (PBS buffer, $\mathrm{pH}=7.4$ ) were recorded with and without treatment with $1 \mathrm{U} / \mathrm{mL} \beta$-gal for 10 minutes (Fig. 2 and S4).

Here, the expected light-up and two-band ratiometric system could be confirmed concerning the nonfluorinated ( $\beta$ Gal-1) and fluorinated probes $\boldsymbol{\beta G G a l - 3}$ and $\boldsymbol{\beta G a l - 4 , ~ r e s p e c t i v e l y . ~ I n ~ f a c t , ~ i n ~ t h e ~ a b s e n c e ~ o f ~}$ enzyme, probes $\boldsymbol{\beta G a l - 3}$ and $\boldsymbol{\beta G a l - 4}$ display their characteristic fluorescence emission in the blue region (470 $\mathrm{nm}$ ), corresponding to the $\beta$-D-galactopyranoside derived benzyl carbamate protected form ( $\boldsymbol{\beta}$ Gal-3 and $\boldsymbol{\beta}$ Gal4). However, after 10 minutes in presence of $1 \mathrm{U} / \mathrm{mL}$ of $\beta$-gal, the emission at $470 \mathrm{~nm}$ was completely suppressed and the new yellow band centered at $560 \mathrm{~nm}$ appeared (fluorophores 4 and 5). Nevertheless, while the reporter dye $\mathbf{4}$ displayed strong enhancement on the fluorescence emission intensity (12-fold related to $\boldsymbol{\beta G a l - 3 ) , ~ c o m p o u n d ~} \mathbf{5}$ was poorly emissive compared to probe $\boldsymbol{\beta G a l - 4 .}$ 
In contrast, after treatment with $\beta$-gal, $\boldsymbol{\beta G a l - 1}$ displayed a spectacular 206-fold increase in the fluorescence emission intensity in the green spectral region $(525 \mathrm{~nm}$, fluorophore 2$)$. Thus, those findings suggest that BGal-1 afforded the higher $\beta$-gal sensitivity among our four probes.
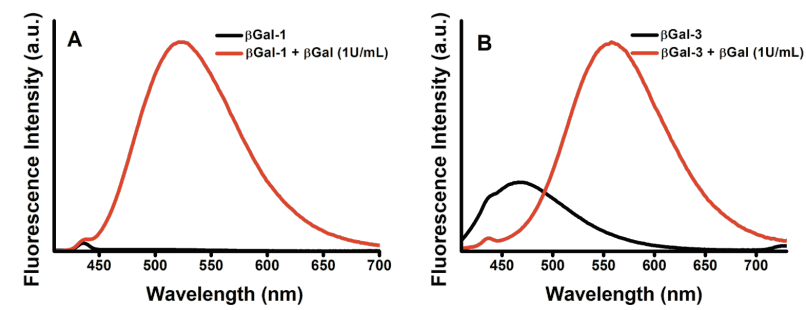

Figure 2. Probes $\boldsymbol{\beta G a l - 1}$ (A) and $\boldsymbol{\beta G a l - 3}$ (B) in absence (black) and presence of $1 \mathrm{U} / \mathrm{mL}$ of $\beta$-galactosidase (red) after 10 minutes in PBS. Conditions: probe concentration $\sim 0.2 \mu \mathrm{M} ; \lambda_{\mathrm{exc}}=380 \mathrm{~nm}$.

\section{Kinetics}

The kinetics of the $\beta$-gal mediated conversion of probes $\boldsymbol{\beta G a l - 1}$ (to 2 ) and $\boldsymbol{\beta G a l - 3}$ (to 4 ) was investigated by analyzing the fluorescence intensity variations of the newly formed ICT bands (525 nm and $560 \mathrm{~nm}$ for $\boldsymbol{\beta G a l -}$ $\mathbf{1}$ and $\boldsymbol{\beta G a l - 3}$, respectively) as a function of time. The response of our probes was compared to the commercially available and commonly employed FDG. The emission spectra at $525 \mathrm{~nm}$ of $\boldsymbol{\beta G a l - 1}$ treated

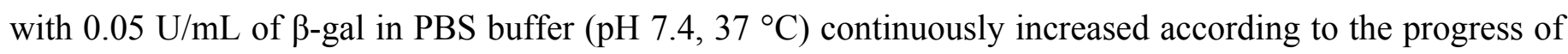
the enzymatic hydrolysis. Emission intensity reached its maximum after 18 minutes of reaction (Fig. 3A). Probe $\boldsymbol{\beta G a l - 3}$ displayed a similar kinetic response. The emission spectra of $\boldsymbol{\beta G a l - 3}$ increased gradually at 560 $\mathrm{nm}$ with a concomitant decrease at $470 \mathrm{~nm}$ (Fig. 3B). The ratio of the emission intensities $\left(\mathrm{F}_{\text {yellow }} / \mathrm{F}_{\text {blue }}\right)$ at 470 $\mathrm{nm}\left(\mathrm{F}_{\text {blue }}\right)$ and $560 \mathrm{~nm}\left(\mathrm{~F}_{\text {yellow }}\right)$ increased by 66-fold upon $\beta$-gal processing of the probe; the maximum was reached after 20 minutes. Pseudo-first order kinetic constants were also accessed ( $\beta$ Gal-1, $0.0045 \mathrm{~s}^{-1}$ and $\boldsymbol{\beta G a l - 3}, 0.0036 \mathrm{~s}^{-1}$, Fig S5). It should be noted that the kinetic responses of both probes were much faster than that of FDG (Fig. 4). Indeed, to attain similar kinetics, the FDG probe should be treated by $4 \mathrm{U} / \mathrm{mL}$ of a $\beta$-gal; i.e. an 80-fold increase in the enzyme concentration (Fig. S5). This comparative experiment highlights the high $\beta$-gal sensitivity of probes $\boldsymbol{\beta G a l - 1}$ and $\boldsymbol{\beta G a l - 3}$ compared with FDG.
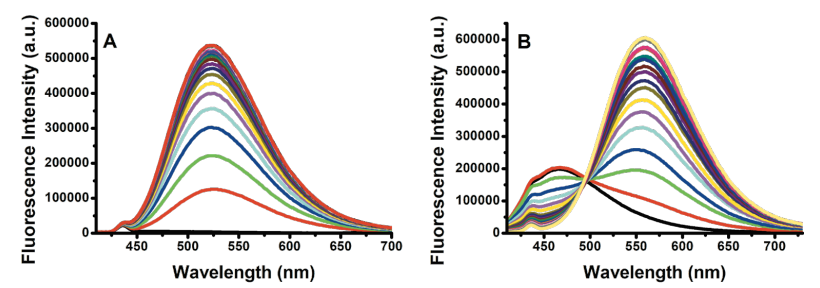

Figure 3. Fluorescence emission spectra of probes $\boldsymbol{\beta G a l - 1}$ (a) and $\boldsymbol{\beta G a l - 3}$ (b) in the presence of $0.05 \mathrm{U} / \mathrm{mL}$ of $\beta$-gal at different times (from 0-25 minutes). Conditions: probe concentration $\approx 0.2 \mu \mathrm{M} ; \lambda_{\mathrm{exc}}=380 \mathrm{~nm}$. 


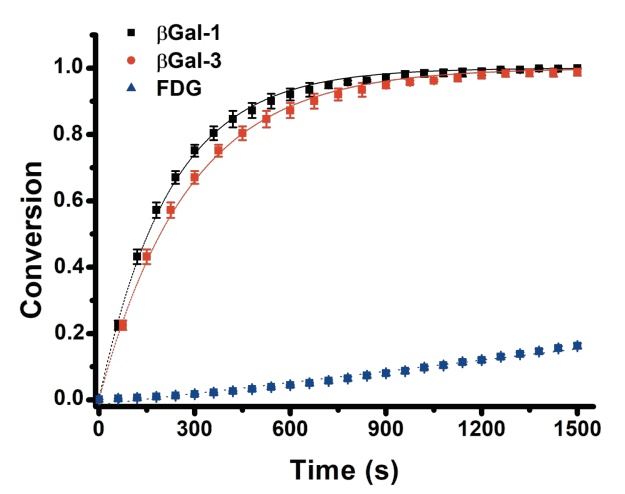

Figure 4. Comparison of the time course of the fluorescence intensity between probes $\boldsymbol{\beta G a l - 1 , \boldsymbol { \beta G a l } - 3}(0.2$ $\mu \mathrm{M})$ and FDG in PBS buffer $\left(\mathrm{pH} 7.4,37^{\circ} \mathrm{C}\right)$ after addition of $\beta$-galactosidase $(0.05 \mathrm{U} / \mathrm{mL})$.

\section{Stability and Fluorescence Emission in Cell}

Considering the superior sensitivity of probe $\boldsymbol{\beta G a l - 1}$ to report $\beta$-gal activity, we decided to study its applicability to biological systems (e.g. (live)-cell imaging). Thus, we started by evaluating its stability in PBS at different $\mathrm{pH}$ values (4.0, 6.0, 7.4 and 9.0). $\boldsymbol{\beta G a l - 1}$ showed high stability in moderately acidic (pH 4.0 and 6.0 ) and basic ( $\mathrm{pH} 9.0$ ) media as almost no residual emission at $525 \mathrm{~nm}$, related to the appearance of the nongalactosylated dye reporter 2 , was observed after 96 hours.

Considering the fluorescence intensity of dye 2, stronger emission was observed in neutral and basic conditions, as expected, while a moderate quenching was observed at pH 4.0 (Fig. S6). Moreover, 2 displayed high photostability (Fig. S10).

Fluorescence emission spectra in A375 melanoma cell lines of $\boldsymbol{\beta G a l - 1}$ and its corresponding non-protected dye 2 were acquired (Fig. S7). It was clearly observed that probe $\mathbf{\beta G a l - 1}$ displays exactly the same fluorescence profile as observed in the in vitro assays (Fig. 3. vs Fig. S7). In addition, no bioconversion of $\boldsymbol{\beta G a l - 1}$ into its fluorescent reporter $\mathbf{2}$ was evidence. To ascertain the selective bioconversion of $\boldsymbol{\beta G a l - 1}$ by $\beta$ galactosidase enzyme, we treated $\boldsymbol{\beta G a l - 1}$ with increasing amounts of A375 cell lysates, supplemented or not with $\beta$-gal (Fig. S8, S9). No fluorescence signals (i.e. conversion of $\boldsymbol{\beta G a l - 1}$ into 2 ) were recorded when the A375 lysate was used without $\beta$-gal supplementation. Thus, this result strongly supports the fact that $\boldsymbol{\beta G a l - 1}$ is selectively processed by $\beta$-Gal and that no interference with other cell constituents is occurring.

Therefore, probe $\boldsymbol{\beta G G a l - 1}$ seems robust enough to be employed in the detection of $\beta$-galactosidase activity under biological conditions.

\section{Limit of Detection}

To further evaluate the response sensitivity of probe $\boldsymbol{\beta G a l - 1}$ to the presence of $\beta$-gal, fluorescence titration experiments were performed. As shown in Fig. S11, in the absence of $\beta$-gal, probe $\boldsymbol{\beta}$ Gal-1 exhibited very weak emission at $525 \mathrm{~nm}$. With the increase of $\beta$-gal concentration from 0 to $0.05 \mathrm{U} / \mathrm{mL}$, the emission band at $525 \mathrm{~nm}$ gradually rose. Notably, the plot fitted linearly with a correlation coefficient of 0.99 in the $\beta$-gal concentration range of $0-0.05 \mathrm{U} / \mathrm{mL}$ (Fig. S12), indicating that $\boldsymbol{\beta}$ Gal-1 is a competent probe for the quantitative detection of low levels of $\beta$-galactosidase. The detection limit was determined to be as low as 
$4.62 \pm 0.46 \times 10^{-5} \mathrm{U} / \mathrm{mL},(3 \sigma / \kappa$, where $\sigma$ is the standard deviation of blank measurements and $\kappa$ is the slope, Fig. S12) which was either in the same range or considerably lower (1000-fold) than the previously reported light-up probes. ${ }^{13,14}$ From these findings, we inferred that probe $\mathbf{\beta G a l - 1}$ displayed readily detectable changes in its fluorescence signature at very low levels of $\beta$-gal $\left(5 \times 10^{-4} \mathrm{U} / \mathrm{mL}\right)$.

\section{Fluorescence imaging of SA- $\beta$-gal in living cells}

Therapy-induced senescence (TIS) represents a novel challenge in cancer drug discovery. This increasing interest in senescence-inducer compounds requires the exploitation of new tools for the development of highthroughput screening. Therefore, we next investigated whether $\mathbf{\beta G a l - 1}$ probe could be used to detect the endogenous senescence-associated $\beta$-galactosidase (SA- $\beta$-gal) on different induced-senescence cancer models.

Two cell lines were chosen for senescence-induced models imaging, including human melanoma A375 cells and human colorectal adenocarcinoma HT-29 cells. SA- $\beta$-gal is overexpressed endogenously in senescent cells, including therapy-induced senescence (such as hydroxyurea $\mathrm{HU}, \mathrm{H}_{2} \mathrm{O}_{2}$, or others). For this study, we chose hydroxyurea (HU) to induce cell senescence and assess the ability of our probe $\boldsymbol{\beta} \mathbf{G a l - 1}$ to monitor SA$\beta$-gal in cells.

Thus, the two cell lines aforementioned were treated with $\mathrm{HU}$ for $96 \mathrm{~h}$, washed with PBS and finally incubated with $0.1 \mu \mathrm{M}$ ßGal-1 for $30 \mathrm{~min}$ at $37^{\circ} \mathrm{C}$. Then cells were washed and fixed with paraformaldehyde (PFA) before observation on confocal microscope. Importantly, compare with X-Gal or FDG reporters that require a $\mathrm{pH}$ modulation step before staining, $\boldsymbol{\beta G a l - 1}$ can be used directly on cells; hence simplifying the staining process. Senescent cells displayed a remarkable increase in cell size (about 10-fold increase for HT-29 senescent-cells). This observation was correlated with the appearance of a strong fluorescence signal when compared to the non-senescent cells (Fig. 5). Moreover, the cytotoxicity of the fluorescent reporter has been evaluated and showed no toxicity; A375 cells showed $100 \%$ and $74.5 \%$ of cell viability after $48 \mathrm{~h}$ of incubation in the presence of $0.1 \mu \mathrm{M}$ and $1.0 \mu \mathrm{M}$ of compound, respectively. Therefore, these results successfully demonstrated that our probe can be applied to visualize endogenous $\beta$-galactosidase activity in living cells. 


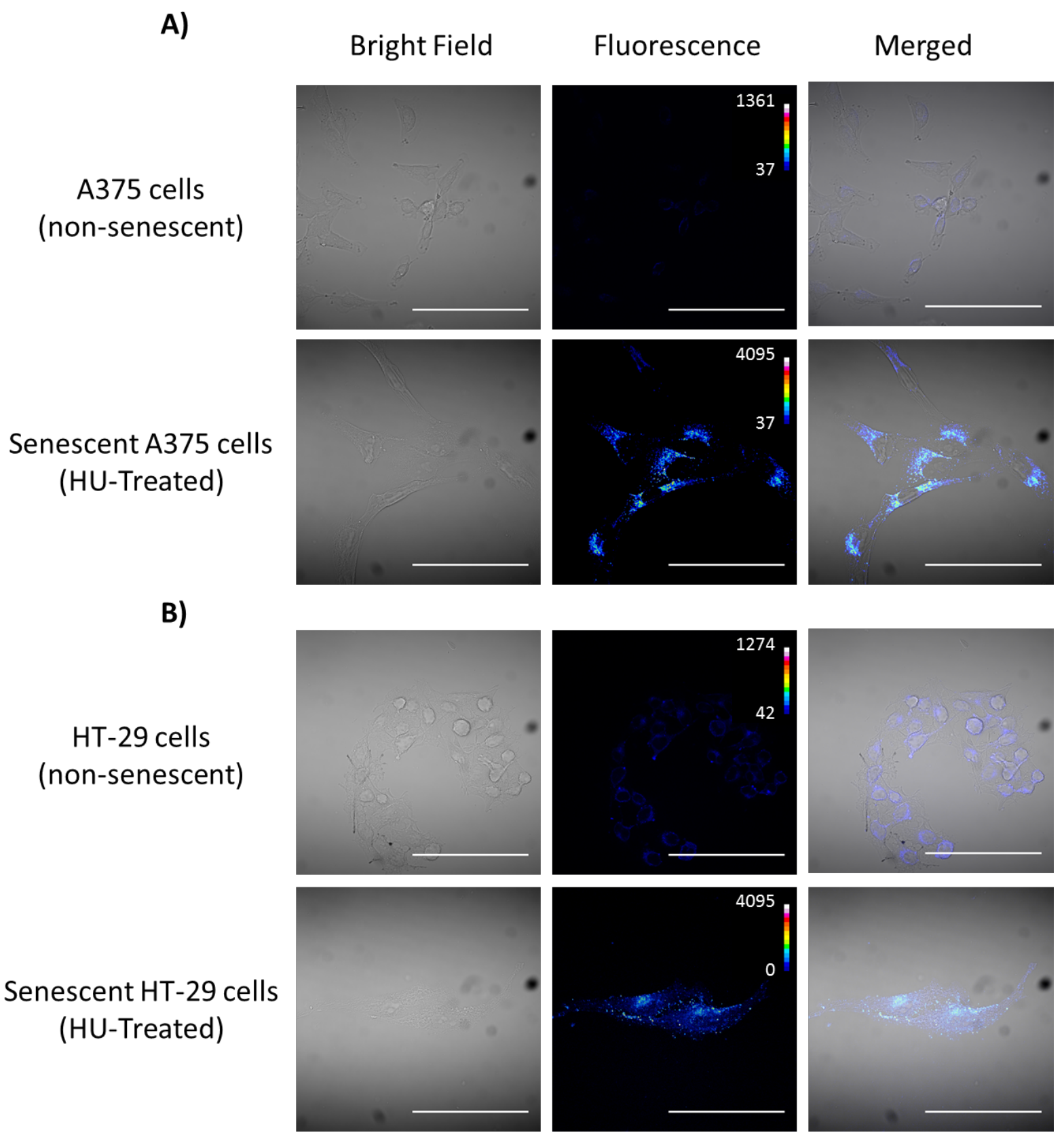

Fig 5. Fluorescence images of normal (HU non-treated) and senescent cells (50 $\mu \mathrm{M} H U$ ) incubated with 0.1 $\mu \mathrm{M}$ ßGal-1. A) human melanoma A375 cells; B) human colorectal adenocarcinoma HT-29. Images were acquired using a confocal microscope with a $63 \mathrm{X}$ NA 1.4 objective; scale bars $=100 \mu \mathrm{m}$.

In addition to the experiment presented on Fig. 5 where we monitored the SA- $\beta$-gal activity within already senescent cancer-cells, we used $\boldsymbol{\beta}$ Gal-1 to monitor the establishment of senescence in live cell (A375 cell line, up to $72 \mathrm{~h}$ ). This live-cell experiment could be performed because of the non-toxicity of our fluorescent reporter. In this experiment, we treated A375 cells with both $\boldsymbol{\beta}$ Gal-1 and HU and monitored the emergence SA- $\beta$-gal activity by fluorescence time-lapse microscopy. As expected, HU-induced senescence was visually corroborated by the progressive increase in cell size from to $24 \mathrm{~h}$ to $72 \mathrm{~h}$ (Fig. 6). This observation was closely correlated with the increase of the fluorescence intensity (Fig. 6B). Conversely, normal A375 cells (HU nontreated, i.e. non-senescent), did not exhibit either morphological changes or fluorescence intensity enhancement. 
Altogether these results supports that, $\boldsymbol{\beta G a l - 1}$ allows the detection of minor increases in SA- $\beta$-gal activity, thus demonstrating the ability of our probe to monitor and detect, in real-time, the senescence at early stages in live cells, without $\mathrm{pH}$ modulation and interference of the senescence inducer treatment (HU).

A)

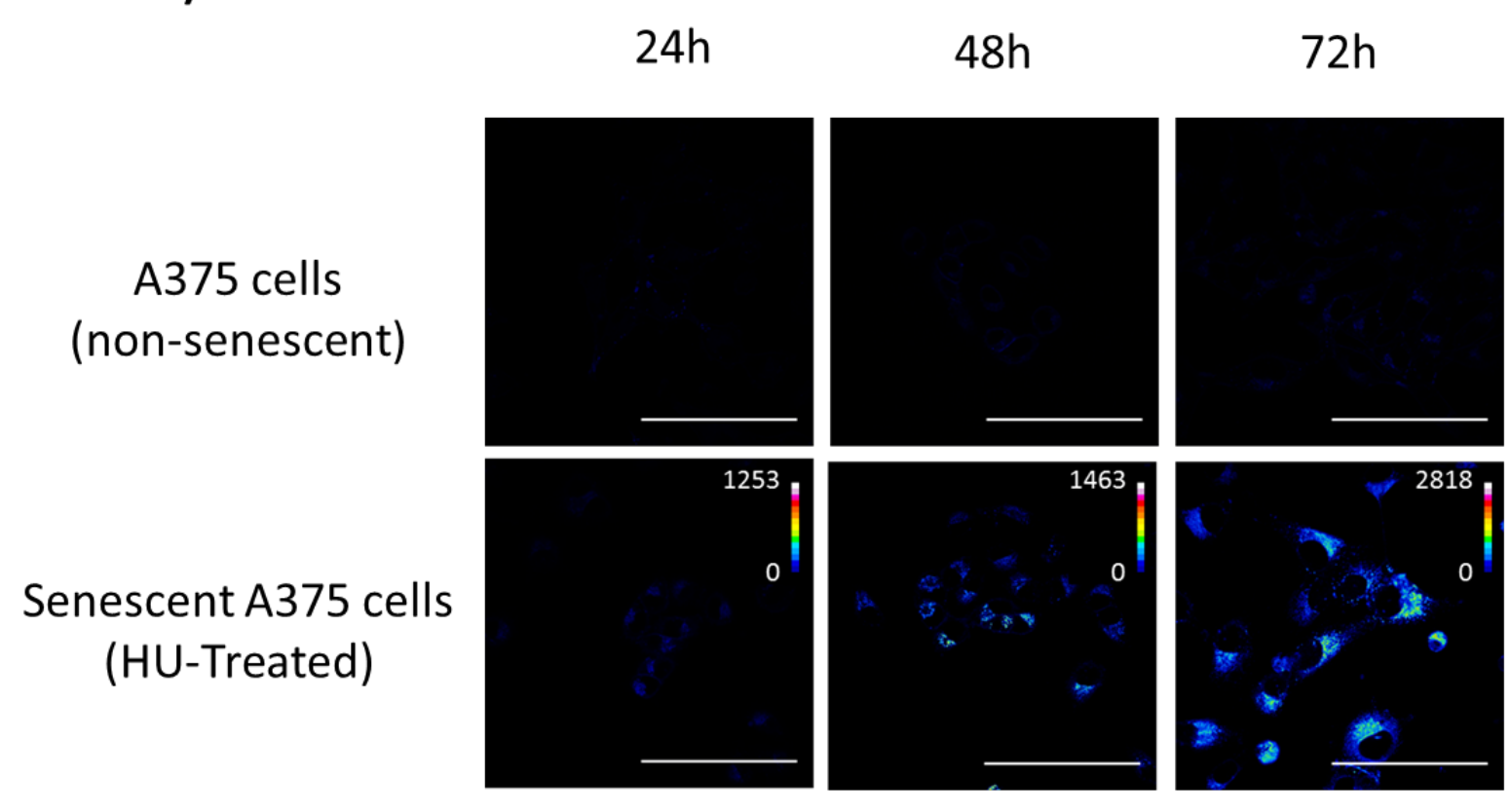

B)

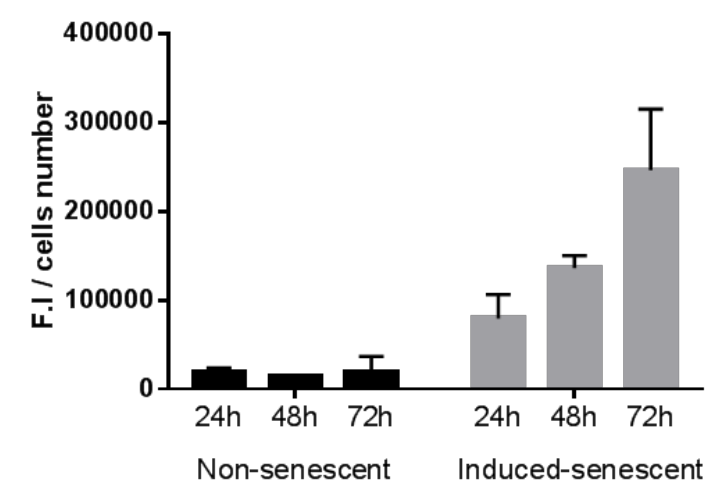

Fig 6. Fluorescence time-lapse microscopy of senescence establishment in human melanoma A375 cells. A) images of A375 non-senescent (non-treated) and induced-senescent cells (50 $\mu \mathrm{M} \mathrm{HU}$ ) incubated with $0.1 \mu \mathrm{M}$ BGal-1 at various times (24, 48 and 72 h). Images were acquired using a confocal microscope with a 63X NA 1.4 objective; scale bars $=100 \mu \mathrm{m}$. B) Quantification of fluorescence intensity of A375 senescence-induced cells treated with $0.1 \mu \mathrm{M}$ ßGal-1.

Next, we evaluated the compatibility of $\boldsymbol{\beta G G a l - 1}$ with flow cytometry analyses. For this purpose, we treated A375 cells with HU at 0,10 and $50 \mu \mathrm{M}$, and assess the applicability of $\boldsymbol{\beta G a l - 1}$ in the quantification of the proportion of senescent cells. After $72 \mathrm{~h}$ of HU treatment, the cells were collected, incubated with $0.1 \mu \mathrm{M}$ of $\boldsymbol{\beta G a l - 1}$ and subsequently analyzed by FACS. As expected, a dose-dependent increase in size (forward scatter, FSC) and granularity (side scatter, SSC) was observed and closely correlated with an increase of fluorescence signal $(72.5 \%$ at $10 \mu \mathrm{M}$ and $86.9 \%$ at $50 \mu \mathrm{M}$, Fig. 7$)$. 
This data demonstrates the applicability of our probes in flow cytometry analyses, a widely used tools on biomedical and clinical research; hence $\boldsymbol{\beta G G a l - 1}$ could be used in the development of a high-throughput screening protocol using flow cytometry.

\section{A375 cells (non-senescent)}

Senescent $A 375$ cells (HU-Treated $10 \mu \mathrm{M}$ )

Senescent A375 cells (HU-Treated $50 \mu \mathrm{M}$ )
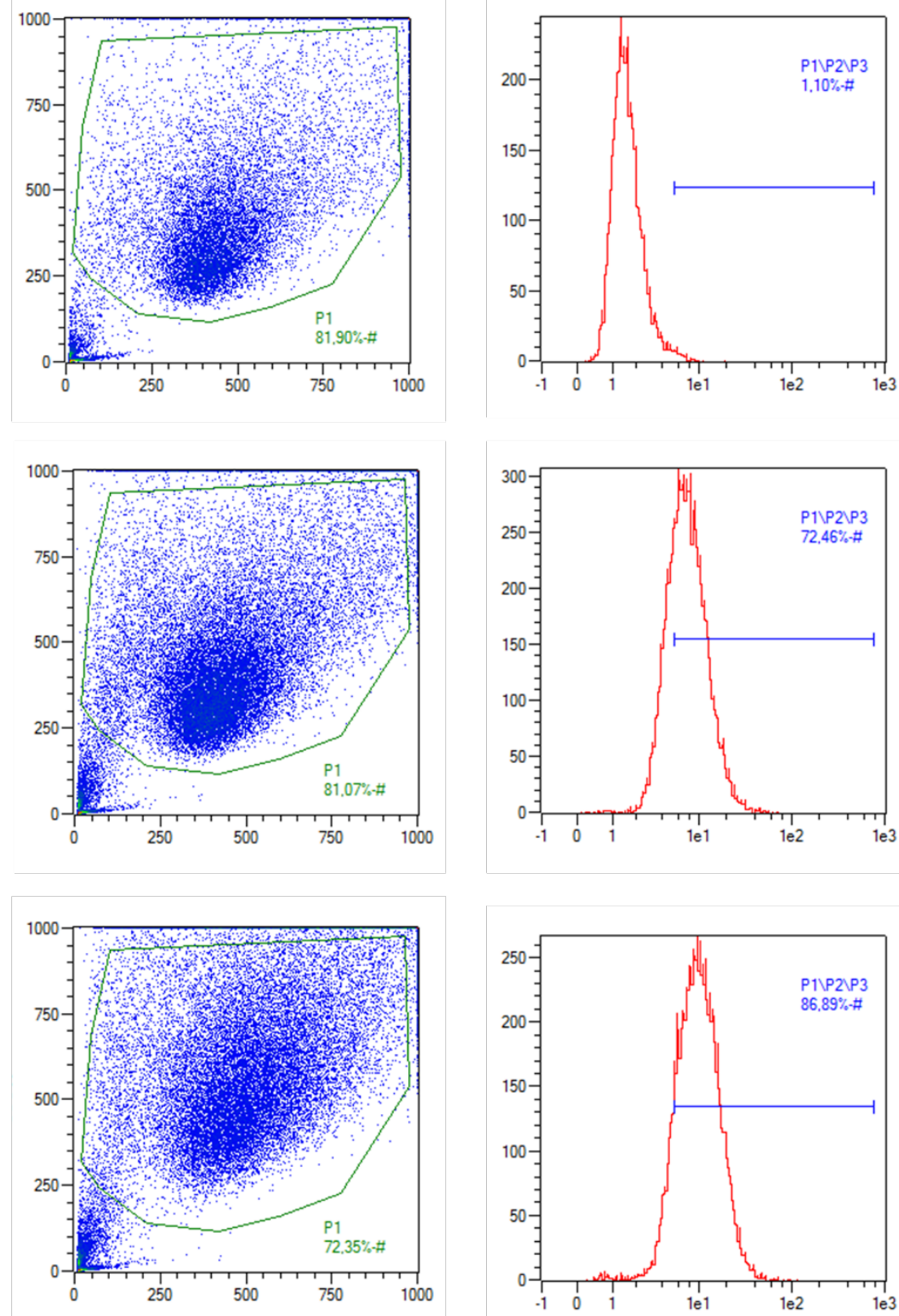

Fig 7. Flow cytometry analysis. SSC/FSC parameters and fluorescence signal have been evaluated by flow cytometry in A375 cells and hydroxyurea induced-senescent A375 cells (10 and $50 \mu \mathrm{M}$ of HU).

\section{Conclusions}

In this study, we designed new small molecule fluorescent probes for the detection of $\beta$-gal activity either in enzymatic or in in vitro experiment in living cells. Among the four probes that were prepared, $\beta$ Gal-1, $\beta$ Gal$\mathbf{3}$ and $\boldsymbol{\beta G a l - 4}$ presented a remarkable enhancement on the kinetic response compared with the other reported turn-on $\beta$-gal probes (4-MUG and FDG). In particular, because of its non-toxicity, stability to hydrolytic degradation, cell permeability and turn-on fluorescence property, probe $\boldsymbol{\beta G a l - 1}$ appeared as powerful and user-friendly fluorescent tool. Indeed, $\boldsymbol{\beta G a l - 1}$ can be used either in fixed or live cells and does not required a 
pH modulation step. It demonstrated an extremely high sensitivity (LOD $\approx 4.62 \times 10^{-5} \mathrm{U} / \mathrm{mL}$ in PBS) together with a high performance in the detection and visualization of minor increases of SA- $\beta$-gal activity in cells. Moreover, $\boldsymbol{\beta G a l - 1}$ allowed the real-time monitoring of the senescence appearance (TIS in A375 cancer cell line), via time-lapse fluorescence microscopy. Applicability of $\boldsymbol{\beta}$ Gal-1 in flow cytometry analysis was also ascertained. Thus it would be compatible with the development of a high-throughput screening for drugdiscovery application in TIS. This initial study focusing on the turn-on probe $\boldsymbol{\beta G G a l - 1}$ will be further extended; notably the use of $\boldsymbol{\beta G a l - 3}$ and $\boldsymbol{\beta G}$ Gal-4 for the ratiometric visualization of SA- $\beta$-gal is currently being assessed in our laboratories.

\section{Conflict of interest}

There are no conflicts of interest to declare.

\section{Acknowledgment}

This work was supported by CNRS, University of Nice Sophia Antipolis, INSERM, Cancéropôle PACA, SATT Sud-Est and CAPES (fellowship to MSF, process number 99999.0011495/2015-01). We also thank Dr. Nedra Tekaya for her help with flow cytometry analyses.

\section{Notes}

${ }^{\dagger}$ These authors (MSF and PD) contributed equally.

\section{Associated Content}

Supporting Information: Supplementary figures, copies of ${ }^{1} \mathrm{H},{ }^{19} \mathrm{~F}$ and ${ }^{13} \mathrm{C}$ NMR and HRMS spectra of all reported compounds; spectra from the photophysical study.

\section{References}

1. N. Brunner, E. W. Thompson, M. Spang-Thomsen, J. Rygaard, K. Dano and J. A. Zwiebel, Eur. J. Cancer, 1992, 28A, 1989-1995.

2. C. J. Buller, X. P. Zang, E. W. Howard and J. T. Pento, Methods Find. Exp. Clin. Pharmacol., 2003, 25, 713-716.

3. Y. Fu and W. Xiao, Methods Mol. Biol., 2006, 313, 257-264.

4. I. G. Serebriiskii and E. A. Golemis, Anal. Biochem., 2000, 285, 1-15.

5. G. P. Dimri, X. Lee, G. Basile, M. Acosta, G. Scott, C. Roskelley, E. E. Medrano, M. Linskens, I. Rubelj, O. PereiraSmith and et al., Proc. Natl. Acad. Sci. USA, 1995, 92, 9363-9367.

6. J. A. Ewald, J. A. Desotelle, G. Wilding and D. F. Jarrard, J. Natl. Cancer Inst., 2010, 102, 1536-1546.

7. S. R. Schwarze, V. X. Fu, J. A. Desotelle, M. L. Kenowski and D. F. Jarrard, Neoplasia, 2005, 7, 816-823.

8. B. D. Chang, E. V. Broude, M. Dokmanovic, H. Zhu, A. Ruth, Y. Xuan, E. S. Kandel, E. Lausch, K. Christov and I. B. Roninson, Cancer Res., 1999, 59, 3761-3767.

9. J. P. Coppe, P. Y. Desprez, A. Krtolica and J. Campisi, Annu. Rev. Pathol., 2010, 5, 99-118.

10. F. Debacq-Chainiaux, J. D. Erusalimsky, J. Campisi and O. Toussaint, Nat. Protoc., 2009, 4, 1798-1806.

11. D. Asanuma, M. Sakabe, M. Kamiya, K. Yamamoto, J. Hiratake, M. Ogawa, N. Kosaka, P. L. Choyke, T. Nagano, H. Kobayashi and Y. Urano, Nat. Commun., 2015, 6, 6463.

12. X. X. Zhang, H. Wu, P. Li, Z. J. Qu, M. Q. Tan and K. L. Han, Chem. Commun., 2016, 52, 8283-8286.

13. J. Huang, N. Li, Q. Wang, Y. Gu and P. Wang, Sens. Actuators, B, 2017, 246, 833-839.

14. G. Jiang, G. Zeng, W. Zhu, Y. Li, X. Dong, G. Zhang, X. Fan, J. Wang, Y. Wu and B. Z. Tang, Chem. Commun., 2017, 53, 4505-4508.

15. B. Lozano-Torres, I. Galiana, M. Rovira, E. Garrido, S. Chaib, A. Bernardos, D. Munoz-Espin, M. Serrano, R. Martinez-Manez and F. Sancenon, J. Am. Chem. Soc., 2017, 139, 8808-8811.

16. H. W. Lee, C. H. Heo, D. Sen, H. O. Byun, I. H. Kwak, G. Yoon and H. M. Kim, Anal. Chem., 2014, 86, 1000110005.

17. M. Safir Filho, S. Fiorucci, A. R. Martin and R. Benhida, New J. Chem., 2017, 41, 13760-13772. 
18. J. Schindelin, I. Arganda-Carreras, E. Frise, V. Kaynig, M. Longair, T. Pietzsch, S. Preibisch, C. Rueden, S. Saalfeld, B. Schmid, J. Y. Tinevez, D. J. White, V. Hartenstein, K. Eliceiri, P. Tomancak and A. Cardona, Nat. Methods, 2012, 9, 676-682.

19. S. A. Spring, S. Goggins and C. G. Frost, Org. Biomol. Chem., 2017, 15, 7122-7126.

20. K. Bhattacharyya and M. Chowdhury, Chem. Rev., 1993, 93, 507-535.

21. A. Rananaware, D. D. La and S. V. Bhosale, RSC Adv., 2015, 5, 63130-63134.

22. J. Yang, Y. Gao, T. Jiang, W. Liu, C. Liu, N. Lu, B. Li, J. Mei, Q. Peng and J. Hua, Mater. Chem. Front., 2017, 1, 1396-1405.

23. The formation of aggregates was confirmed by DLS measurements; however, sedimentation during the course of the analysis impeded the accurate determination of the size of the particles. 